<総 説 $>$

(受理 : 平成 28 年 8 月 26 日)

\title{
リビングラジカル重合を用いた粘着剂の開発と産業化 Development and Industrialization of Pressure Sensitive Adhesive Using a Living Radical Polymerization
}

河 野 和 浩* Kazuhiro KAWANO

\section{1.はじめに}

ラジカル重合反応は，多くのビニルモノマーを穏和な条 件下で重合できる汎用性を持っているため，工業的に広く 用いられていることは周知のと抢りである。しかしながら 従来のラジカル重合では成長末端の制御がなされていない ため，生成するポリマーの分子量分布や構造を制御する ことは困難である。これに対し，リビングラジカル重合 (LRP) は本来ラジカル重合が有している多くの極性官能 基と共存できる汎用性と，モノマーや溶媒の純度などにあ まり影響されない簡便性とを保ちつつ，成長末端の制御を 行うことが可能な重合法である。このことから生成するポ リマーの分子量とその分布を制御して合成することができ る。また“生きた”重合末端を利用することで，ブロック 共重合体の合成や，重合末端の選択的な变換反応を行うこ とができる。さらにはグラフト，櫛形，多分岐重合体など の様々なモルフォロジーを持つマクロ分子を制御して合成 することも可能であることから，ナノテクノロジーを支え る機能性高分子材料合成の基盤技術となることが期待され ている。

\section{2. リビングラジカル重合とは ${ }^{1)}$}

従来のラジカル重合（フリーラジカル重合：FRP）は 三つの素反応，開始反応，成長反応，および停止反応から 成り立っている。一旦, 開始ラジカルが, 熱, 光, 酸化・ 還元などの様々な刺激により生成すると，それがモノマー

$*$ 大塚化学 (株) 化学品開発部

東京都千代田区神田司町 2-2 \% 101-0048

Otsuka Chemical Co., Ltd. Market \& Research Department 2-2 Kanda Tsukasa-machi, Chiyoda-ku, Tokyo 101-0048, Japan
に次々と反応し成長反応が起こる。これにより生じた重合 末端ラジカルは再結合反応や不均化反応による停止反応を 受けて，デッドポリマーとなる。この条件下では開始ラジ カルの生成は非可逆的に進行すると共に，停止反応速度は 一般に拡散律速に近い速度で起こる。したがって，発生し たひとつひとつのラジカル種は通常 1 秒足らずの間に停止 反応を受ける。

一方，リビングラジカル重合（LRP）では図 1 に示す ように，活性な重合末端ラジカルの生成に対して適切な官 能基を持つドーマント種（ラジカル反応において休眠種と も呼ばれる安定な化学種）と呼ばれる前駆体 $\mathrm{P}-\mathrm{X}$ から， ラジカルが可逆的に生成する方法が用いられる。 $\mathrm{P}-\mathrm{X}$ が 活性化されることで生成した P ラジカルが，モノマーと 反応して鎖長を伸ばした後，不活性化されて鎖長が伸びた ドーマント種が生成する機構である,

具体的なドーマント種の活性化方法としては，熱，光， 触媒などの外部刺激による結合一解離機構, 酸化還元など を利用した原子移動機構，連鎖移動剤を用いた交換連鎖機 構が存在し，それぞれの重合法の特徴が現れる。

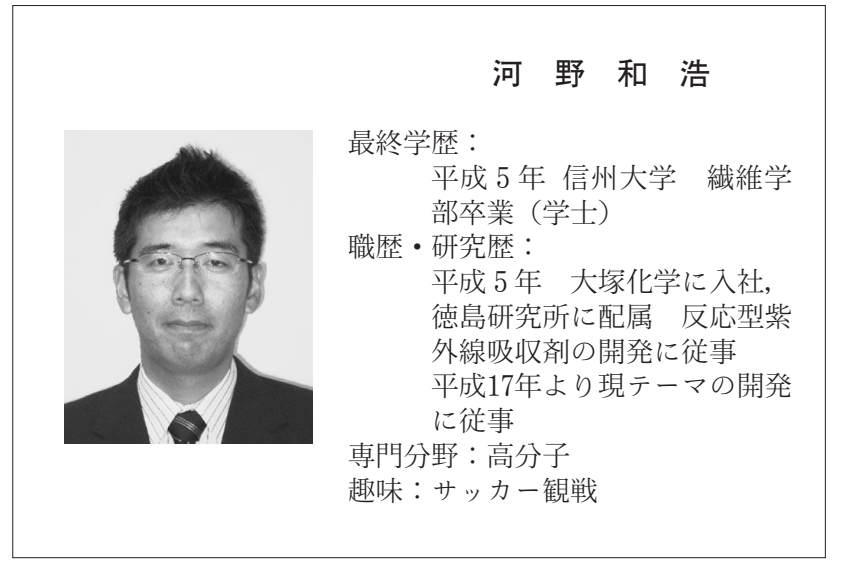


【リビングラジカル重合の一般機構】

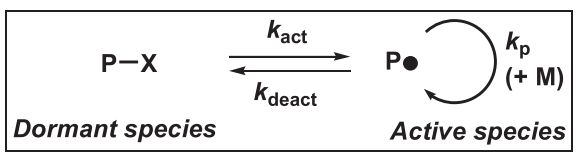

1）解離一結合機構（dissociation-combination）

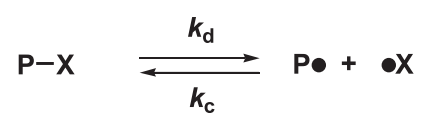

2) 原子移動機構 (atomtransfer)

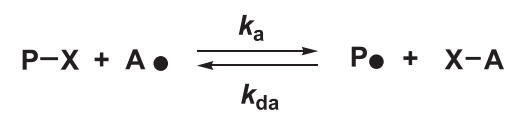

3) 交換連鎖機構（degenerative chain transfer）

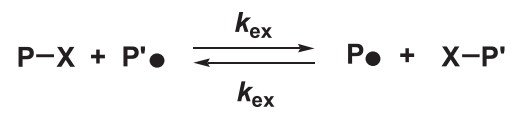

図 1 リビングラジカル重合の一般的反応機構

一般的にリビングラジカル重合か否かの判定基準として, 下記の特徴が挙げられる。

1）数平均分子量（Mn）が重合率に比例して増加する。

2) 生成する重合体の分子量がモノマーと開始剤との仕 込み比により制御できる。

3）生成する重合体の分子量分布（Mw/Mn）が狭い。

4）重合体の活性末端を利用し，ブロックポリマーや末 端官能基化されたポリマーの合成が可能。

\section{3. 有機テルル化合物を用いるリビングラジカル重 合法 $(\text { TERP 法 })^{2)}$}

我々は京都大学の山子茂教授のグループと共に, 有機テ ルル化合物をプロモーターとして使用するリビングラジカ ル重合法 (TERP 法：Organo tellurium-mediated living radical polymerization）の研究開発を行ってきた。その 結果，この重合技術は学術的に高い新規性を持つのみなら ず, 実際の産業界で要求されている種々の重合体の合成に
おいても，大変有効であることが明らかになってきた。

TERP 法の反応機構は, 従来のリビングラジカル重合 機構とは異なり, 熱解離機構と交換連鎖機構が共存してい ることが確認されており，この特異的な性質により，この 重合法の最大の特徵である高い汎用性が発現される。

表 1 に沉用的なビニルモノマーの代表であるメタクリル 酸メチル (MMA)，スチレン (St）及びアクリル酸 $\mathrm{n}$-ブ チル（BA）の重合結果を示す。いずれのモノマーに対し ても, 一般的なラジカル重合同様の穏和な重合条件下で, 工業的に使用されている様々な重合方法（溶液重合, バル ク重合，懸濁重合）を用い，制御良く重合可能である。な かでも BA の場合, 数平均分子量 $(\mathrm{Mn})$ で 70 万に近い 超高分子量領域で屯, 分子量分布 $(\mathrm{Mw} / \mathrm{Mn})$ が 1.3 台之 高度な制御が実施可能である。もう一つ特徴的な結果とし て，水を媒体に用いる懸濁重合に適用しても，まったく問 題なく重合制御が可能ということが挙げられる。

次に従来の一般的なリビングラジカル重合では制御しに くいと言わ机ている極性モノマーの重合結果を図 2 示す。 カルボキシル基, 水酸基, アミノ基, アミド基及びニトリ ル基などの極性官能基を有するビニルモノマーを，いずれ あ保護することなく直接重合することができる。これ以外 にあ非共役モノマーあ重合可能であり, 適用出来るモノマー 種の広さを示す一例である。

次いでリビング重合の特徵であるブロックポリマーの合 成例を図 3 示す3)。TERP 法を用いた場合，重合順序に制 限はなく, $\mathrm{AB}$ ブロックポリマーも $\mathrm{BA}$ ブロックポリマー あ同様に重合可能であり，さらには $\mathrm{ABA}, \mathrm{ABC}$ などの トリブロックポリマーも合成することができる。同様に， 分子量 50 万という高分子量のブロックポリマー合成も可 能である。

\section{4. 粘着剂開発への応用}

我々は TERP 法の特徵の一つである超高分子量領域で の分子量分布制御を活用できる用途として粘着剂に着目し

表 1 TERP 法による汎用モノマーの重合例

\begin{tabular}{|c|c|c|c|c|c|c|}
\hline En. & $\begin{array}{l}モ ノ マ ー \\
(\text { equiv.) }\end{array}$ & 重合 法 & $\begin{array}{l}\text { 重合条件 } \\
{\left[{ }^{\circ} \mathrm{C} / \mathrm{hr}\right]}\end{array}$ & $\begin{array}{c}\text { 転 化率 } \\
{[\%]}\end{array}$ & $\mathrm{Mn}$ & $\mathrm{Mw} / \mathrm{Mn}$ \\
\hline 1 & MMA $\left(\begin{array}{lll}1 & 0 & 0\end{array}\right)$ & 溶 液 重 合 & $50 / 20$ & 99 & 12,800 & 1. 17 \\
\hline 2 & 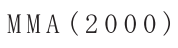 & 懸 濁 重 合 & $60 / 22$ & 93 & 200,600 & 1.22 \\
\hline 3 & $\mathrm{St}\left(\begin{array}{lll}3 & 0 & 0\end{array}\right)$ & 懸 濁 重 合 & $90 / 27$ & 99 & 25,800 & 1. 11 \\
\hline 4 & St $\left(\begin{array}{llll}3 & 0 & 0 & 0\end{array}\right)$ & 懸 濁 重 合 & $90 / 77$ & 97 & 154,0000 & 1.55 \\
\hline 5 & $\mathrm{BA}(100)$ & バルク重 合 & $50 / 22$ & 99 & 12,800 & 1. 17 \\
\hline 6 & $\mathrm{BA}\left(\begin{array}{llll}4 & 0 & 0 & 0\end{array}\right)$ & バルク重合 & $50 / 13$ & 96 & 482,700 & 1.37 \\
\hline 7 & 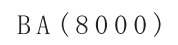 & バルク重合 & $50 / 41$ & 95 & 692,200 & 1.37 \\
\hline
\end{tabular}




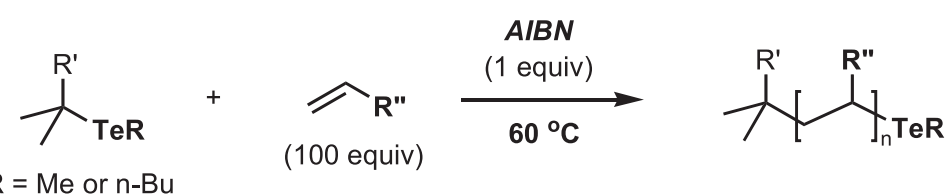<smiles>C=Cc1ccc(OCCC)cc1</smiles>

$13 \mathrm{~h}, 92 \%$ $M_{\mathrm{n}}=14300$

$\mathrm{PDI}=1.15$<smiles>C=CN</smiles>

$3 \mathrm{~h}, 99 \%^{b}$ $M_{\mathrm{n}}=37800$

$\mathrm{PDI}=1.16$<smiles>C=Cc1ccccn1</smiles>

$3 \mathrm{~h}, 99 \%$ $M_{\mathrm{n}}=32200$

$\mathrm{PDI}=1.18$

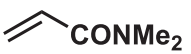

$3 \mathrm{~h}, 99 \%^{b}$ $M_{\mathrm{n}}=17400$ $\mathrm{PDI}=1.18$<smiles>C=Cc1ccncc1</smiles>

2 h, $94 \%$ $M_{\mathrm{n}}=35800$

$\mathrm{PDI}=1.10$

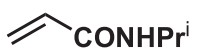

3 h, $99 \%{ }^{b}$ $M_{\mathrm{n}}=13800$ $\mathrm{PDI}=1.16$<smiles>C=C(C)C(=O)COC</smiles>

$2 \mathrm{~h}, 90 \% \mathrm{a}, b$ $M_{\mathrm{n}}=22300$

$\mathrm{PDI}=1.18$<smiles>C=CC(=O)O</smiles>

1 h, $99 \%$ $M_{\mathrm{n}}=7500$ $\mathrm{PDI}=1.35$

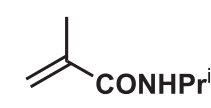

$16 \mathrm{~h}, 96 \%$ a,b

$M_{\mathrm{n}}=14200$

$\mathrm{PDI}=1.11$

${ }^{a}(\mathbf{M e T e})_{2}$ was added. ${ }^{b} \mathrm{DMF}$ was used as solvent. ${ }^{c} 1,4$-dioxane was used as solvent

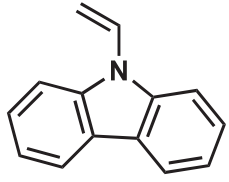

$6 \mathrm{~h}, 99 \%^{\mathrm{c}}$ $M_{\mathrm{n}}=7100$

図 2 TERP 法による極性モノマーの重合例

1）ブロック共重合体重合例

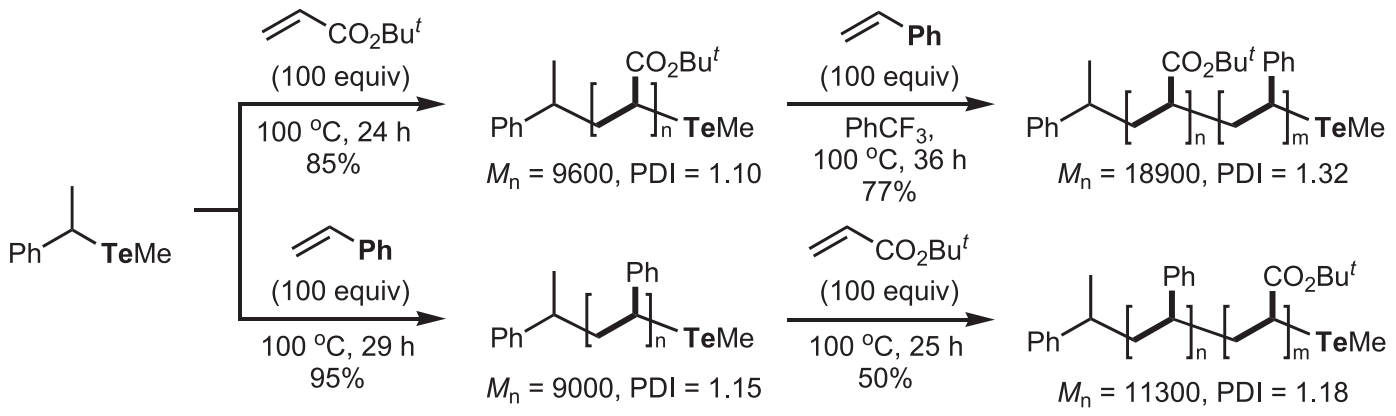

2）高分子量ブロック共重合体重合例<smiles>CCOC(C)(C)C(C)(C)C</smiles>
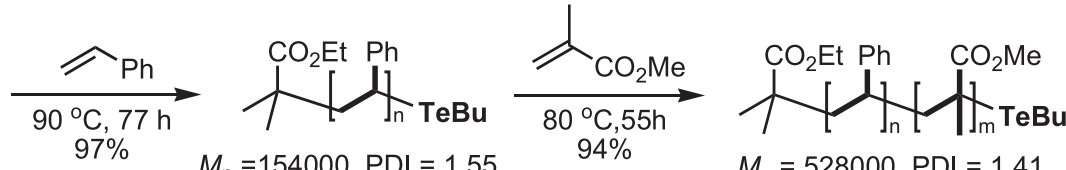

図 3 TERP 法によるブロックポリマーの重合例

表 2 重合法による粘着物性の差異

\begin{tabular}{|c|c|c|c|c|c|}
\hline \multirow{2}{*}{ 重合法 } & \multicolumn{2}{|c|}{ 分子量 } & \multirow{2}{*}{$\begin{array}{l}\text { 剥離力 } \\
\mathrm{N} / 25 \mathrm{~mm} \\
\end{array}$} & \multirow{2}{*}{$\begin{array}{l}\text { ボール } \\
\text { タック } \\
\end{array}$} & \multirow{2}{*}{$\begin{array}{c}\text { 保持力 } \\
40^{\circ} \mathrm{C} \times 1 \mathrm{~kg} \\
\end{array}$} \\
\hline & Mw & $\mathrm{Mw} / \mathrm{Mn}$ & & & \\
\hline TERP & 581,600 & 1.24 & 7.4 & 5 & $26 \mathrm{~min}$ \\
\hline FRP & 703,800 & 3.44 & 16.6 & 6 & $2 \mathrm{~min}$ \\
\hline
\end{tabular}

被着体：SUS BA 板 測定方法：JIS Z0237-2000

た。粘着剤の開発を行うにあたり, TERP 法により得ら れるポリマーの特徵確認を目的に，粘着剂のモデル化合物 として BA のホモポリマーを TERP 法ならびに FRP 法に より合成した。得られたポリマーについて粘着物性の比較

\section{を行った。結果を表 2 に示す。}

TERP 法により合成された粘着剤は FRP 品と比較し, 剥離力が約半分になっている他, 保持力試験で 10 倍以上 の保持時間を示しており，凝集力が向上することがわかっ 


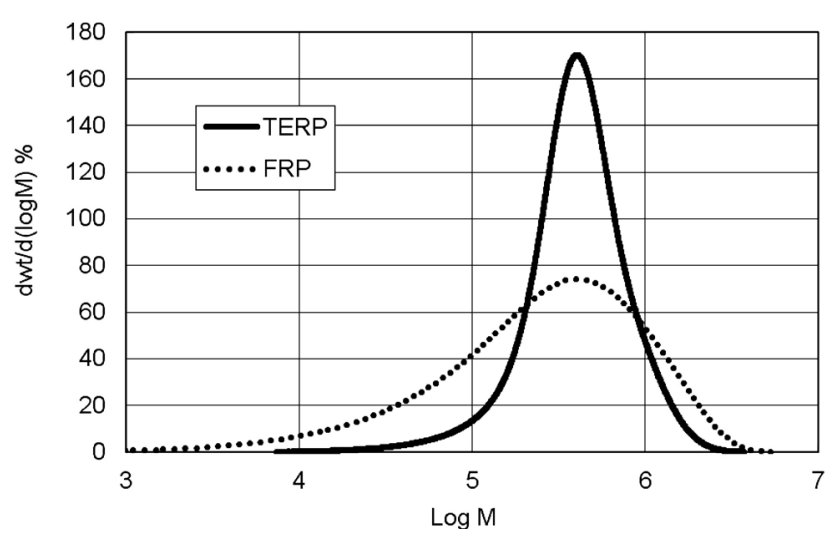

図 4 重合法による分子量分布の差異 (GPC チャート)

た。これは TERP 法では分子量分布が制御されており, 図 4 の GPC チャートに示すように粘着剂中の低分子量成 分（オリゴマー）が低減されている。オリゴマーはその分 子量故にポリマー鎖中での移動能力が高く, 粘着剤中では 可塑剂として作用するが，TERP 法により合成された粘 着剤は FRP 品と比較しオリゴマーの量が低減されており, 凝集破壊が起こりにくくなっていると考えられる。

また一般に粘着剂の樹脂組成では架橋反応により凝集力 を上げるために, 架橋反応点としてのカルボキシル基や, 水酸基を含む極性モノマーが共重合される。前述の通り TERP 法ではこれらの極性官能基を保護することなく共 重合することができるため，粘着剤を制御よく重合する技 術として適している。

粘着剤のモデル化合物として BA とメタクリル酸 2 -ヒド ロキシェチル (2-HEMA) とのコポリマー（重量比 95/5） について分子量の異なる試料を合成し, 粘着物性を評価し た結果を表 3 に示す。

TERP 法では架橋反応点として水酸基を有する $2-$ HEMA を各高分子鎖中に均一に導入することが可能であ

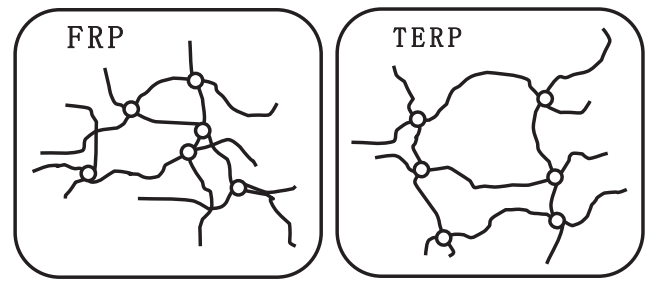

$\bigcirc$...架橋点

図 5 重合法による架橋構造の差異

る。このため分子量だけでなく, 架橋システムの精密制御 が可能となり，その結果として得られた粘着剤はオリゴマー 成分が低減され，かつ未架橋部分がないため，凝集力に優 れた粘着層が形成される。FRP 品と比較し耐熱性に優れ, 剥離時の被着体污染が低減されることがわかった。

一方で剥離力にっいては FRP 品が低い結果となってい る。この結果については図 5 に示すように, FRP 品は分 子量分布が広いため, TERP 品と比較し，バルク成分の 架橋密度が高くなることが原因と考えている。つまり， FRP 品は架橋密度が高いためバルクの応力緩和効果が小 さく, 界面での剥離に移行するのに対し，TERP 品は偏 りのないネットワークの形成により架橋密度が低くなるこ とで優れた応力緩和性を発現することから，剥離力が大き くなっているものと考える。

次にモデル化合物として BA とアクリル酸 4-ヒドロキ シブチル（4-HBA）とのコポリマー（重量比 98/2）につ いて TERP 法ならびに FRP 法により合成し，架橋後のゲ ル分率が $80 \%$ になるよう調製した試料の機械特性（引っ 張り試験）を評価した結果を図 6 に示す。

TERP 法により合成された粘着剂は FRP 品と比較し, プラトー領域が長く，破断強度，破断伸びが大きい。前述 のとおり，TERP 法ではオリゴマー成分が低減されてい るため機械特性が改善されたと考えられる。

表 3 P (BA-co-HEMA) の粘着物性比較

\begin{tabular}{|c|c|c|c|c|c|c|c|c|c|}
\hline \multirow{2}{*}{$\begin{array}{l}\text { 重 合 } \\
\text { 法 }\end{array}$} & \multirow{2}{*}{$\begin{array}{c}M w \\
\left(\times 10^{3}\right)\end{array}$} & \multirow{2}{*}{$\mathrm{Mw} / \mathrm{Mn}$} & \multicolumn{4}{|c|}{ 剥離力 $[\mathrm{N} / 25 \mathrm{~mm}] /$ 糊残 り* } & \multirow{2}{*}{$\begin{array}{l}\text { ボール } \\
\text { タック }\end{array}$} & \multicolumn{2}{|c|}{ 保 持力 } \\
\hline & & & \multicolumn{2}{|c|}{$23^{\circ} \mathrm{C}, 30 \mathrm{~min}$} & \multicolumn{2}{|c|}{$80^{\circ} \mathrm{C}, 24 \mathrm{hr}$} & & $80^{\circ} \mathrm{C}$ & $100^{\circ} \mathrm{C}$ \\
\hline \multirow{5}{*}{ TERP } & 230 & 1.39 & 6.81 & A & 11.97 & B & 6 & $>1440$ & $>1440$ \\
\hline & 436 & 1.61 & 4.75 & A & 8.37 & B & 5 & $>1440$ & $>1440$ \\
\hline & 560 & 1.53 & 3.81 & A & 8.22 & A & 6 & $>1440$ & $>1440$ \\
\hline & 767 & 1.60 & 3.33 & A & 5.93 & A & 3 & $>1440$ & $>1440$ \\
\hline & 958 & 1. 91 & 2.85 & A & 5.41 & A & 2 & $>1440$ & $>1440$ \\
\hline FRP & 721 & 6.36 & 1.65 & C & 2.10 & C & 5 & $16 \mathrm{~min}$ & - \\
\hline
\end{tabular}

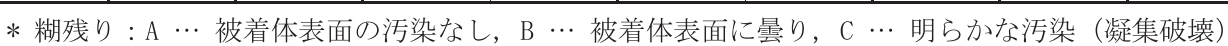
配合条件：ポリマー固形分 100 部に対し架橋剤としてコロネート L-55E（イソシアネート系硬化剂, 東ソー（株）製）を 4 部配合。

基材 : $25 \mu \mathrm{m}$ 厚 PET 乾燥後膜厚 : $25 \mu \mathrm{m}$ 被着体 : SUS BA 板 測定方法 : JIS Z0237-2000 


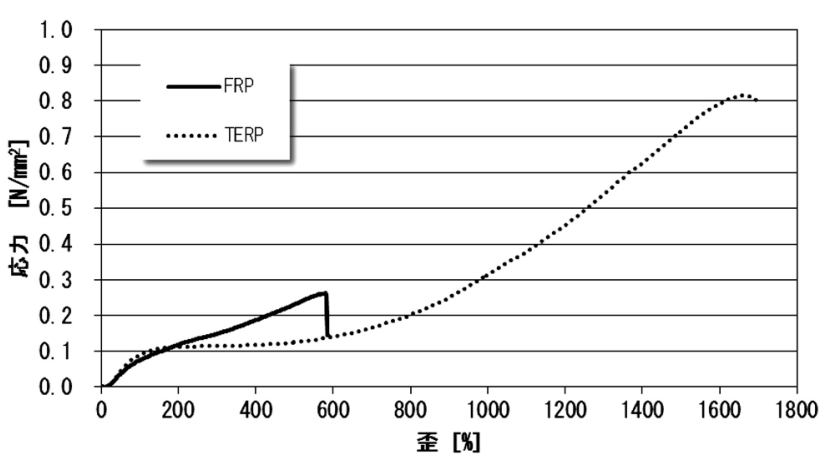

図 6 重合法による機械特性の差異

\section{TERP 法を応用した粘着剤／ TERPLUS N シリーズ}

大塚化学では前記の結果を踏まえ，TERP 法を応用し た粘着剤／TERPLUS N シリーズを展開している。下記 に TERPLUS N シリーズの特徴を示す。

1）耐熱性・耐污染性に優れる（粘着剤成分中のオリゴ マーの低減)。

2）高い凝集力（粘着剤成分中のオリゴマーの低減）。

3）応力緩和性に優れる（架橋成分の均一導入）。

主な用途：光学フィルム関連粘着剂，電子材料関連粘着 剤，ホットメルト粘着剂等

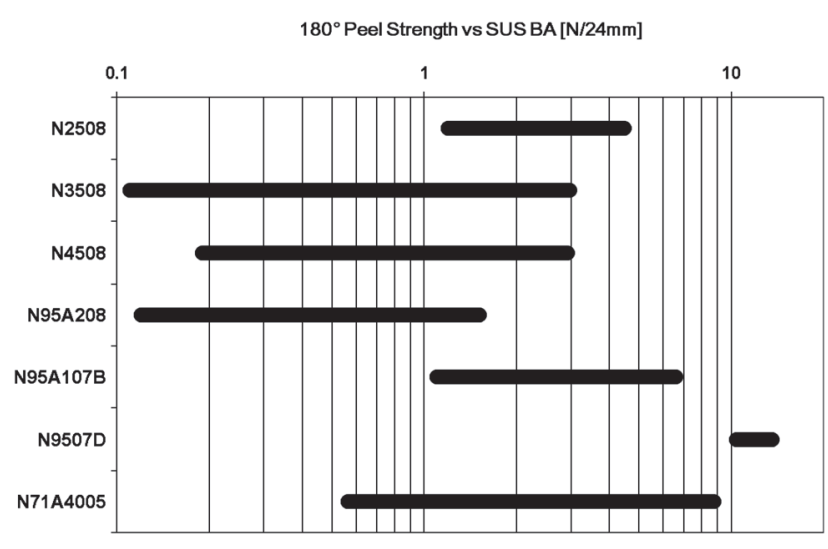

被着体：SUS BA 板 測定方法：JIS Z0237-2009 図 7 代表グレードの粘着力適用範囲

以下，代表グレードについて紹介する（表 4, 図 7)。ま た代表グレードの他にも顧客の要望に応じたカスタマイズ 対応も行っている。

\section{6. 構造制御を用いた粘着剂展開}

以上はリビングラジカル重合法（TERP 法）を用いた ランダムポリマーの粘着剤への応用例を紹介した。前述の 通り, リビングラジカル重合法の特徵として構造制御, つまりはブロックポリマーを合成することができるため, SIS（スチレンーイソプレンースチレン）のような ABA 型トリブロックポリマーの各ブロックの相分離による疑似

表 4 代表グレード一覧

\begin{tabular}{|c|c|c|c|c|}
\hline グレード & 固形 分 & 主成分 & 官 能 基 & 特 徵 \\
\hline $\mathrm{N} 2508 \mathrm{~A}$ & $25-35 \%$ & $2-\mathrm{EHA}^{* *}$ & 水酸 基 & 応力緩和性 \\
\hline N 3508 & $15-25 \%$ & B A & 水 酸 基 & $\begin{array}{l}\text { 耐污染性、微粘着力、 } \\
\text { 酸フリー }\end{array}$ \\
\hline N 4508 & $25-35 \%$ & 2 - EHA & 水 酸 基 & $\begin{array}{l}\text { 応力緩和性、なじみ性、 } \\
\text { 酸フリー }\end{array}$ \\
\hline N95A 208 & $15-25 \%$ & $\mathrm{BA}$ & 水酸 基 & 耐污染性、弱粘着力 \\
\hline N95A $107 \mathrm{~B}$ & $17-27 \%$ & B A & 水 酸 基 & $\begin{array}{l}\text { 耐 污 染 性、耐熱性、 } \\
\text { 中粘着力 }\end{array}$ \\
\hline N9507D & $17-27 \%$ & BA & 水 酸 基 & $\begin{array}{l}\text { 耐污染性、強粘着力、 } \\
\text { 酸フリー }\end{array}$ \\
\hline N71A4005* & $10-20 \%$ & B A & $\begin{array}{l}\text { カルボン } \\
\text { 酸 基 }\end{array}$ & 耐污染性、強粘着力 \\
\hline $\mathrm{N} 43 \mathrm{~A} 210^{*}$ & $10-20 \%$ & 2 - EHA & 水 酸 基 & $\begin{array}{l}\text { 耐 污 染 性、耐熱 性、 } \\
\text { 微粘着力 }\end{array}$ \\
\hline
\end{tabular}

*: 開発グレード

**：アクリル酸 2-エチルヘキシル 


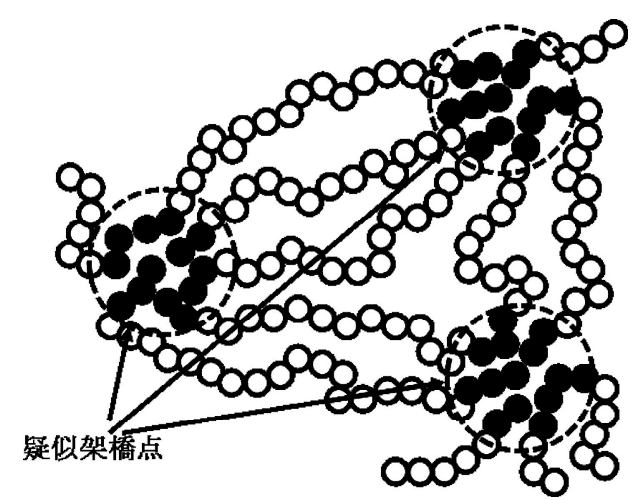

図 8 架橋剂レス粘着剤の高機能化

架橋構造を利用した架橋剤レス粘着剤への展開が可能であ る(図 8)。

従来の SIS 樹脂を, アクリル樹脂に置き換えることに より下記が期待される。

1）接着力のコントロール（被着体に合わせた粘着成分 の極性制御)

2) 耐光性改善

3）耐熱性改善

4) 光学特性改善

TERP 法では前述の通り, その汎用性の高さから化学 架橋成分の導入など，その分子設計の自由度を利用し，ア クリル系架橋剤レス粘着剂の高機能化が期待される。

\section{7. 生産体制}

大塚化学では TERP 法を応用したポリマーの市場開拓 および量産技術検討を進めた結果, 徳島工場内に専用プラ ントを建設するに至った。量産化が困難と言われていたり ビングラジカル重合技術の工業化に成功した世界に数少な
い量産プラントである。当プラントは数百 $\mathrm{kg}$ レベルから の試作から数 t レベルの生産に対応可能であり, 2014 年 5 月の稼動開始以降, 「TERPLUS N シリーズ」の他, 顔 料分散剤の「TERPLUS D シリーズ」について生産を行っ ている。

\section{8. まとめ}

今回リビングラジカル重合法（TERP 法）を用いた粘 着剂を紹介した。分子量を制御することにより従来のラジ カル重合法と比較し, 特徴的な物性を示すことが確認され た。

今後 TERP 法は, 化学・電子・光学・医療などの最先 端分野に用いられる機能性ポリマーの製造技術として大变 有用な手段になると考えられる。例えばミクロ相分離構造 やミセル構造などの高次構造制御によるポリマー材料の高 機能化や, 光・温度応答性, 導電性等の機能性部位が導入 されたポリマー材料の合成など色々な応用展開が期待され る。

\section{文献}

1) (a) Matyjaszewski, K., Davis, T.P., Handbook of Radical Polymerization, Wiley-Interscience, New York, (2002). (b) Matyjaszewski, K., Controlled Living Radical Polymerization. Progress in ATRP, NMP, and RAFT, American Chemical Society, Washington, DC (2000).

2) (a) Yamago, S., Iida, K., Yoshida, J., J. Am. Chem. Soc., 124, 2874 (2002). (b) Yamago, S., Iida, K., Nakajima, M., Yoshida, J., Macromolecules, 36, 3793 (2003). (c) Goto, A., Kwak, Y., Fukuda, T., Yamago, S., Iida, K., Nakajima, M., Yoshida, J., J. Am. Chem. Soc., 125, 8720 (2003).

3) Yamago, S., Iida, K., Yoshida, J., J. Am. Chem. Soc., 124, 13666 (2002). 